\title{
Studies on Effect of Month and IBA Concentration of Air Layering in Guava (Psidium guajava L.) cv. Sardar
}

\author{
B. Manga*, P. Jholgiker, G.S.K. Swamy, G. Prabhuling and N. Sandhyarani \\ Department of Fruit science, KRCCH, Arabhvi, University of Horticultural Sciences, Bagalkot \\ *Corresponding author:
}

\begin{tabular}{|c|c|}
\hline & A B S T R A C T \\
\hline $\begin{array}{l}\text { Ke y w o r d s } \\
\text { Guava, Month, Air } \\
\text { layering, IBA }\end{array}$ & \multirow{3}{*}{$\begin{array}{l}\text { An investigation on effect of month and IBA concentration on success of air layering in } \\
\text { guava cv. Sardar at the Department of Fruit Science, Kittur Rani Channamma College of } \\
\text { Horticulture, Arabhavi, University of Horticultural Sciences, Bagalkot, during the period } \\
\text { of } 2012-2013 \text {. The results revealed that minimum days for root initiation ( } 84 \text { days), } \\
\text { maximum number of roots }(12.10) \text {, higher rooting }(33.33 \%) \text { and survival percentage } \\
(100.00 \%) \text { in layers prepared in the month August applied with IBA- } 4000 \mathrm{ppm} \text {. Growth } \\
\text { of these layers was vigorous as depicted by maximum number of sprouts }(8.25) \text {, number of } \\
\text { leaves }(22.64) \text { and shoot length }(59.00 \mathrm{~cm}) \text { at } 90 \text { days after separation from mother plant } \\
\text { layers placed under shade house for hardening. This was followed by layers treated with } \\
\text { IBA-3000 ppm prepared in August month. While in control, there was poor response for } \\
\text { root initiation, rooting percentage and number of roots than all treatments. }\end{array}$} \\
\hline Article Info & \\
\hline $\begin{array}{l}\text { Accepted: } \\
\text { 26 April } 2017 \\
\text { Available Online: } \\
10 \text { May } 2017\end{array}$ & \\
\hline
\end{tabular}

\section{Introduction}

Guava is one of the most common and popular fruit crop in area and production after mango, banana and citrus. It has been in cultivation in India since early $17^{\text {th }}$ century and gradually become a crop of commercial significance. It is quite prolific beared and highly remunerative without much care (Singh, 2007). It cultivated commercially in tropical and subtropical regions of the world. Guava is a rich source of vitamin ' $\mathrm{C}$ ' and minerals. Best quality jelly can be prepared from fruits as these are rich in pectin. Guava is successfully propagated sexual method (Zamir et al., 2003) and asexual methods cutting, grafting, budding and air layering. But air layering is one of the most important commercial methods in practice for propagation of guava has been stressed by
Sharma et al., (1991) and Chandrappa and Gowda (1998). Air layering with the help of growth substances is more efficacious and to be that best method of vegetative propagation of guava by Tingwa and Abbadi (1968) and Mujumdar and Mukherjee (1978) in rooting. However the success of air layering varies from place to place.

The climate of the region plays a crucial and significant role in realizing better success rates with this method (Rymbai and Satyanarayana Reddy, 2010). Some reviews suggest that the success in air layering of guava can be improved by adopting correct time of air layering and use of auxins for induction of rooting. These points keep in view an experiment was conducted to identify 
optimum season of air layering and correct concentration of IBA for higher success rate.

\section{Material and Methods}

The experiment was carried out Studies on effect of month and IBA concentration of air layering in guava (Psidium guajava L.) cv. Sardar during the period of 2012 - 2013, at the Department of Fruit Science, Kittur Rani Channamma College of Horticulture, Arabhavi, University of Horticultural Sciences, Bagalkot, The experiment was laid out in Two factorial Randomized Block Design with three months air layering and five levels of IBA concentrations along with control (untreated). Thus 15 treatments were replicated three times. Thirty layers prepared each treatment formed a unit.

\section{Selection of plants and shoots for air layering}

Layering was performed on 16 year old healthy guava cv. Sardar plants, planted at a spacing of 6x6 $\mathrm{m}$ in square system of planting under rainfed condition. On the selected trees one year old shoots of pencil size thickness were selected randomly for air layering. The average length of the selected shoots was 60 $\mathrm{cm}$ and showing smooth bark.

\section{Method of application}

In the selected shoots, a ring of bark about 2$2.5 \mathrm{~cm}$ was girdled carefully with the help of a sharp budding knife and the exposed portion was rubbed with the back of budding knife without causing any injury to the underlying wood, it was done just below the node by giving two circular cuts about $45-60 \mathrm{~cm}$ below the top end of a shoots. The IBA solution of different concentration as per treatment was applied evenly above the upper portion of the cut of the ring with the help of cotton. Control shoot were left as such. A sleeve $(15 \times 20 \mathrm{~cm})$ of transparent polythene (150 gauges) was then lowered on the ringed portion of the shoot. The distal end of the sleeve was tied on the stem at a distance of 5$6 \mathrm{~cm}$ below the ring with the help of gunny thread. The rooting media i.e. sphagnum moss was firmly filled into the sleeve and the upper end was also sealed with gunny thread to minimize the evaporation of moisture.

\section{Detachment and lifting of rooted air layers}

The air layers were separated from the mother plants after induction of rooting (when roots were visible) by given three installations cut at an interval of one week, so as to reduce the shock of sudden detachment. The first ' $V$ ' shaped cut given $1 / 3^{\text {th }}$ of the total diameter of the layered shoot, the second cut given to further deepen the first cut to about half of the shoot thickness and the final cut was given at the time of transplanting.

Total nitrogen and carbohydrates content of scion shoots collected during different months were determined by the standard methods (Sadasivam and Manickam, 2005). The data was statistical analysed by following procedure as suggested by Panse and Sukhatme (1978).

\section{Results and Discussion}

\section{Effect of month of air layering and IBA concentration on rooting parameters}

The depicted of data in Table 1 revealed that layers prepared in the month of August treated with IBA- 4000 ppm was superior all over treatment for days taken for root initiation, per cent rooting and number of roots, which were registered highest per cent rooting, least number of days (84 days) for root initiation and maximum number of roots per layer (12.10). 
Table.1 Effect of month and different IBA concentrations of air layering on rooting and growth parameters in guava cv. Sardar under Arabhavi conditions

\begin{tabular}{|c|c|c|c|c|c|c|}
\hline & Treatments & $\begin{array}{l}\text { Days taken } \\
\text { for root } \\
\text { initiation } \\
\text { (days) }\end{array}$ & $\begin{array}{l}\text { No. of } \\
\text { roots/ } \\
\text { layer }\end{array}$ & $\begin{array}{l}\text { Number of } \\
\text { sprouts / } \\
\text { layer } \\
90 \text { DAS }\end{array}$ & $\begin{array}{c}\text { Number of } \\
\text { leaves / } \\
\text { layer } \\
90 \text { DAS }\end{array}$ & $\begin{array}{c}\text { Average Shoot } \\
\text { length }(\mathrm{cm}) \\
90 \text { DAS }\end{array}$ \\
\hline Factor - I & Month of layering & & & & & \\
\hline $\mathrm{T}_{1}$ & Layering in August & 90.03 & 7.57 & 6.29 & 17.55 & 48.33 \\
\hline $\mathbf{T}_{2}$ & Layering in September & 93.00 & 5.12 & 3.86 & 11.08 & 34.20 \\
\hline $\mathbf{T}_{\mathbf{3}}$ & Layering in October & 93.13 & 4.23 & 3.15 & 9.02 & 29.73 \\
\hline S. Em \pm & & 0.89 & 0.27 & 0.14 & 0.38 & 0.81 \\
\hline CD@ $9 \%$ & & 2.58 & 0.78 & 0.43 & 1.11 & 2.36 \\
\hline Factor - II & IBA Concentration & & & & & \\
\hline $\mathbf{I}_{1}$ & Control (Untreated) & 99.28 & 0.08 & 1.33 & 3.34 & 12.66 \\
\hline $\mathbf{I}_{2}$ & IBA 1000ppm & 94.33 & 6.10 & 3.77 & 12.38 & 35.88 \\
\hline $\mathbf{I}_{3}$ & IBA 2000ppm & 90.66 & 6.15 & 4.98 & 13.34 & 38.77 \\
\hline $\mathbf{I}_{4}$ & IBA 3000ppm & 89.66 & 6.34 & 5.24 & 15.14 & 45.22 \\
\hline $\mathbf{I}_{5}$ & IBA4000ppm & 86.33 & 9.51 & 6.85 & 18.56 & 54.55 \\
\hline S. Em \pm & & 1.15 & 0.35 & 0.19 & 0.49 & 1.05 \\
\hline CD @ 5\% & & 3.34 & 1.01 & 0.55 & 1.44 & 3.05 \\
\hline \multicolumn{7}{|l|}{ Interactions } \\
\hline & $\mathrm{T}_{1} \mathrm{I}_{1}$ & 94.85 & 0.27 & 4.00 & 10.00 & 38.00 \\
\hline & $\mathrm{T}_{1} \mathrm{I}_{2}$ & 92.33 & 7.90 & 5.67 & 16.53 & 42.67 \\
\hline & $\mathrm{T}_{1} \mathrm{I}_{3}$ & 90.00 & 8.64 & 6.38 & 18.67 & 48.33 \\
\hline & $\mathrm{T}_{1} \mathrm{I}_{4}$ & 89.00 & 8.97 & 7.16 & 19.95 & 53.67 \\
\hline & $\mathrm{T}_{1} \mathrm{I}_{5}$ & 84.00 & 12.10 & 8.25 & 22.64 & 59.00 \\
\hline & $\mathrm{T}_{2} \mathrm{I}_{1}$ & 101.00 & 0.00 & 0.00 & 00.00 & 00.00 \\
\hline & $\mathrm{T}_{2} \mathrm{I}_{2}$ & 96.00 & 5.47 & 3.88 & 11.55 & 34.33 \\
\hline & $\mathrm{T}_{2} \mathrm{I}_{3}$ & 92.00 & 5.56 & 4.45 & 11.31 & 36.00 \\
\hline & $\mathrm{T}_{2} \mathrm{I}_{4}$ & 90.00 & 5.80 & 4.33 & 13.97 & 45.33 \\
\hline & $\mathrm{T}_{2} \mathrm{I}_{5}$ & 86.00 & 8.78 & 6.64 & 18.62 & 55.33 \\
\hline & $\mathrm{T}_{3} \mathrm{I}_{1}$ & 102.00 & 0.00 & 0.00 & 00.00 & 00.00 \\
\hline & $\mathrm{T}_{3} \mathrm{I}_{2}$ & 94.67 & 4.94 & 1.76 & 9.07 & 30.67 \\
\hline & $\mathrm{T}_{3} \mathrm{I}_{3}$ & 90.00 & 4.27 & 4.12 & 10.06 & 32.00 \\
\hline & $\mathrm{T}_{3} \mathrm{I}_{4}$ & 90.00 & 4.27 & 4.24 & 11.52 & 36.67 \\
\hline & $\mathrm{T}_{3} \mathrm{I}_{5}$ & 89.00 & 7.67 & 5.67 & 14.45 & 49.33 \\
\hline S. Em \pm & & 1.99 & 0.60 & 0.33 & 0.86 & 1.82 \\
\hline $\mathrm{CD} @ 5 \%$ & & 5.78 & 1.75 & 0.96 & 2.49 & 5.29 \\
\hline $\mathrm{CV}(\%)$ & & 3.75 & 18.64 & 13.01 & 11.89 & 8.46 \\
\hline
\end{tabular}

DAS - days after separation from mother plant during hardening 
Table.2 Effect of season on Carbohydrates: Nitrogen ratio in the shoots used for airlayering in guava (Psidium guajava L.) cv. Sardar

\begin{tabular}{|cccc|}
\hline Month & $\begin{array}{c}\text { Total carbohydrates } \\
(\boldsymbol{\%})\end{array}$ & $\begin{array}{c}\text { Total nitrogen } \\
(\boldsymbol{\%})\end{array}$ & C:N ratio \\
\hline $\mathrm{T}_{1}$-August-2012 & 10.23 & 0.96 & 10.62 \\
$\mathrm{~T}_{2}$ - September-2012 & 9.70 & 0.95 & 10.18 \\
$\mathrm{~T}_{3}$ - October-2012 & 8.90 & 0.89 & 10.00 \\
$\mathrm{SEm} \pm$ & 0.36 & 0.01 & 0.55 \\
$\mathrm{CD} @ 5 \%$ & 1.23 & 0.02 & 1.91 \\
$\mathrm{CV}(\%)$ & 7.41 & 1.50 & 10.75 \\
\hline
\end{tabular}

Fig.1 Monthly weather data recorded during the period of investigation

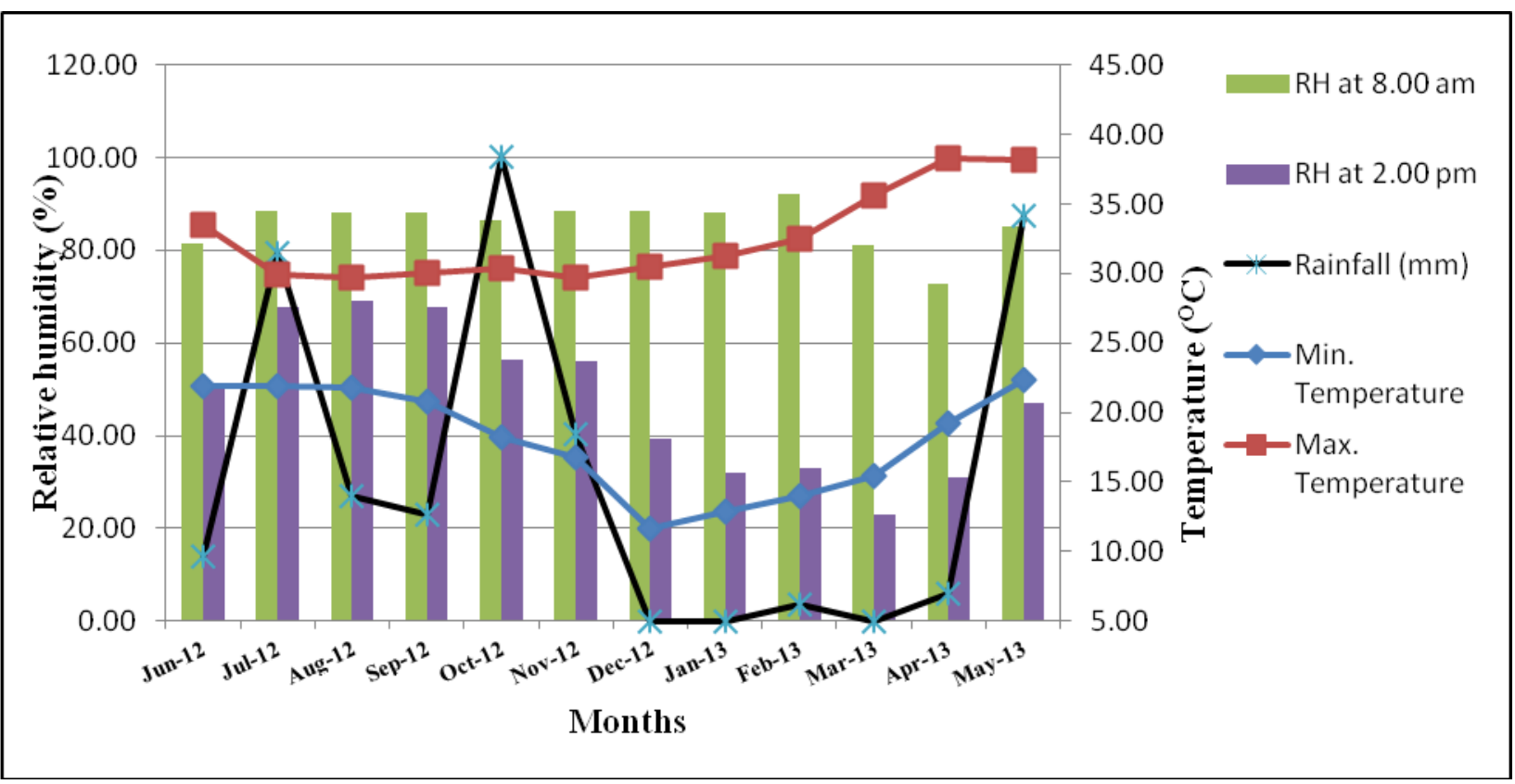


Fig.2 Effect of month and IBA time of air layering on percent rooting and survival percentage in guava (Psidium guajava L) cv. Sardar

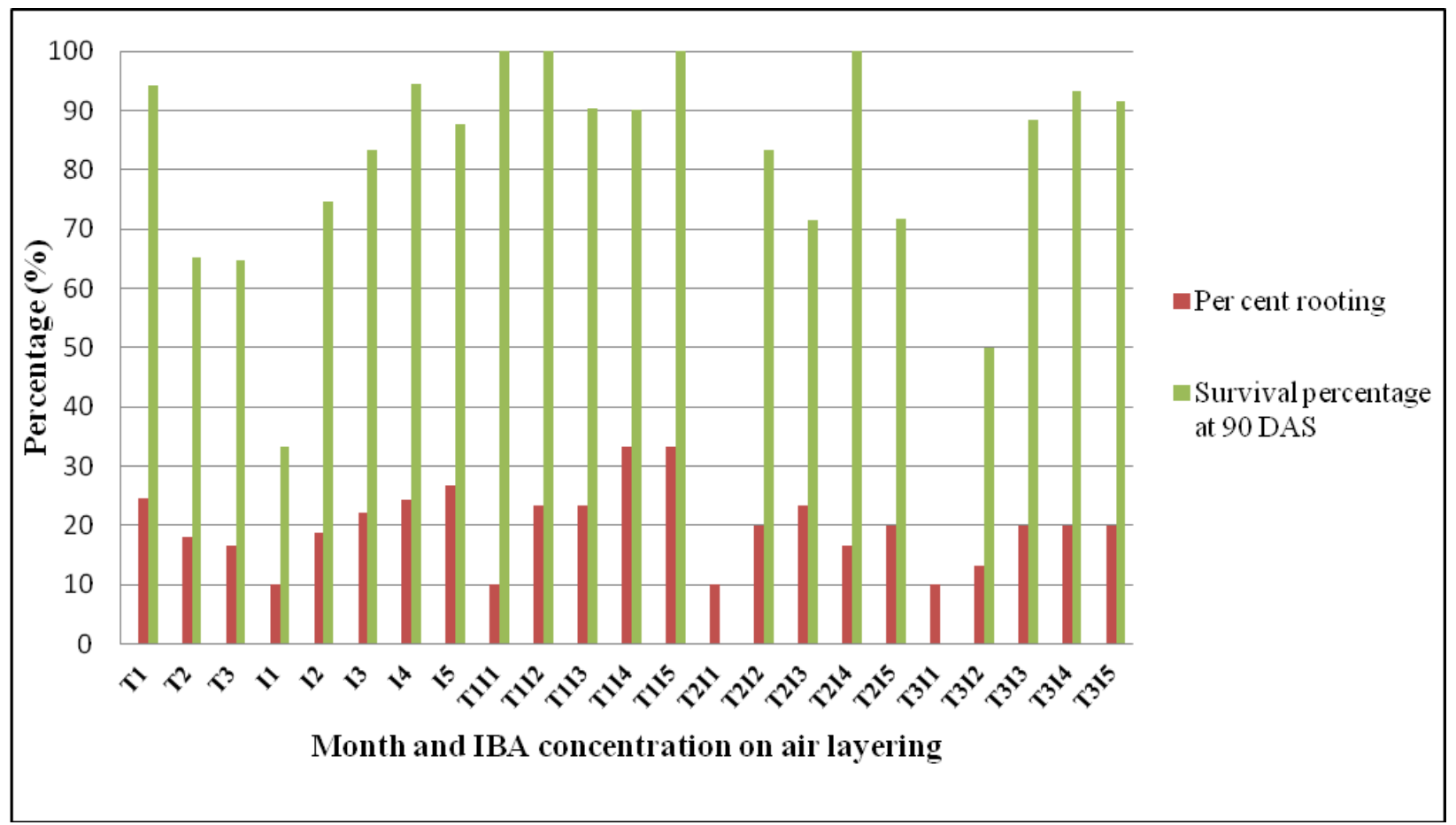

This was followed by layers treated with IBA - 3000 ppm prepared in August month. This may be attributed to the varying weather conditions (Fig 1). Presence of high relative humidity coupled with occurrence of rains and optimum temperature might favoured early rooting. The physiological condition of mother plant greatly decides the efficiency of rooting (Nanda and Anand, 1970). In the present investigation, the physiological condition of shoots available for layering during August was favourable for root initiation and subsequent development as a resulted higher percent rooting. This was further supported with availability of shoots higher levels of carbohydrates and better $\mathrm{C}$ : $\mathrm{N}$ ratio (Table 2). The sap movement in the shoot may be fast as layering month was preceded with good rainfall during June and July months (Fig 1). The present results are in conformity with reports of Alkhatib (1986) in mango, Bhagat et al., (1999) and (Rymbai and Satyanarayana Reddy, 2010) in guava. IBA at higher concentration had helped in triggering the activity of hydrolyzing enzymes like amylase, invertase (Prasad et al., 1990), which catalysis the degradation of starch into sugars required during initial substances and their downward movement increase number of roots and per cent rooting (Tyagi and Patel, 2004). These results were conformity with the findings of Kumar and Syamal (2005), Singh (2001) in guava and Gowda et al., (2006) in rose apple.

Effect of month of air layering and IBA concentration on vegetative parameters during hardening under shade house condition

Data presented in Table 1 significant difference showed among the month of air layering, IBA concentrations and their interactions on vegetative parameters viz., 
number of sprouts, number of leaves, shoot length and survival percentage of layers at 90 days after separation from mother plant. In the present investigation results was found significantly highest in layers prepared August month treated with IBA- 4000 ppm concentration, vigrous growth was reflected in number of sprouts (8.25), number of leaves (22.64), shoot length $(59.00 \mathrm{~cm})$ and survival percentage during hardening in shade house. Similar findings obtain by Tyagi and Patel (2004), Karunakara (1997) and Rymbai and Reddy (2011) in guava.

The growth parameters of the layers depends on the pre- condition shoots on mother plant, the speed and number of roots formation on layer and post separation environment to which the layer is exposed (Sharma et al., 1975). This might be due to the congenial weather conditions prevailed during these month triggered cell activity resulted in early sprouting, number of sprouts and shoot length. In August month higher accumulation of Carbohydrates and $\mathrm{C}: \mathrm{N}$ ratio (Table 2), which readily served as a reservoir of food for new growth reflected in layers.

Good survival percentage of layers noted in layers prepare in the month of August treated with IBA- 4000 ppm (Fig. 2). This might be attributed favourable external environmental factors, good sun shine, aeration, optimum temperatures and relative humidity (Fig. 1) during root initiation, quality of roots, subsequent growth and development of layers.

Transplanted layers having better root system, they could absorb sufficient water and other nutrients from soil and ultimately resulting higher survival percentage. Similar findings were reported by Rymbai and Sathyanarayana Reddy (2010), Kumar and Syamal (2005) and Chandrappa and Gowda (1998) in guava.

\section{References}

Alkhatib, A. S., 1986, Effect of season and growth regulators on rooting of air layers of alphonso and mallika cultivars of mango (Mangifera indica L.). M. Sc. (Agri.) Thesis, Univ. Agric. Sci., Bangalore.

Bhagat, B. K., Jain, B. P., Singh, C. and Chowdhary, B. M., 1999, Success and survival of intergeneric grafts in guava (Psidium guajava L.). J. Res. Birsa Agric. Univ., 11 (1): 79-81.

Chandrappa and Gowda, V. N., 1998, Influence of auxin and 1, 2, 3, acid on rooting of guava air layers. Mysore $\mathrm{J}$. Agric. Sci., 32: 59-66.

Chandrappa and Gowda, V. N., 1998, Influence of auxin and 1, 2, 3, acid on rooting of guava air layers. Mysore J. Agric. Sci., 32: 59-66.

Gowda, V. N., Shyamalamma, S. and Ragavendra Prasad, G. C., 2006, Influence of Auxins and 1, 2, 4 Acid on Rooting of Litchi (Litchi chinensis Sonn.) air Layers. Acta Hort., 727: 7378.

Karunakara, J., 1997, Studies on induction of rooting in shoots of juvenile plants in guava (Psidium guajava L.). M. Sc. (Agri.) Thesis, Univ. Agric. Sci., Dharwad.

Kumar, K. and Syamal, M. M., 2005, Effect of etiolation and plant growth substances on rooting and survival of air-layers of guava. Indian J. Hort., 62 (3): 290-292.

Mukherjee, S. K. and Chatterjee, B. K., 1978, Effect of etiolation and growth regulators on air layering of jackfruit (Artocarpus heterophyllus Lam.). Indian J. Hort., 35: 1-4.

Nanda, K. K. and Anand, V. K., 1970, Seasonal changes in auxin affects on rooting of stem cuttings of Populus nigra and its relationship with 
mobilization of starch. Physiol. Plant., 23: 99-107.

Prasad, P. V., Suryanaryana, V. and Naramnaidu, 1990, Studies on certain aspects of veneer grafting in mango. South Indian Hort., 38 (1): 1-7.

Rymbai, H. and Reddy, G. S. N., 2011, Influence of open field and polyhouse nursery on survival characters of rooted layers in guava (Psidium guajava L.). Life sciences Leaflets, 21: 996 - 1002.

Rymbai, H. and Sathyanarayana Reddy, G., 2010, Effect of IBA, time of layering and rooting media on air-layers and plantlets survival under different growing nursery. Indian J. Hort., 67 (4): 99-104.

Sadasivam, S. and Manickam, A., 2005, In Bioichemical Methods, New Age International publishers.

Sharma, K. K., Sandhu, A. S., Bajwa, M. S. and Dhillon., B. S., 1975, Effect of indole butyric acid and napthalene on the rooting of air-layers of guava (Psidium guajava L.). J. Res. Punjab Agric. Uni., Ludhiana, 12 (1): 23-25.
Sharma, R. S, Sharma,T. R. and Sharma, R. C., 1991, Influence growth regulators and time of operation on rootage airlayering in guava (Psidium guajava L.) cv. Allahabad Safeda. Orissa J. Hort., 19 (1): 41 - 45.

Singh, G., 2007, Recent development in production of guava. Acta Hort., 735: 161-176.

Singh, M., 2001, Efficacy plant growth regulators, their concentration and wrappers on rooting success and survival air layered guava twigs. Crop Res. Hissar., 21 (2): 153-16.

Tingwa, P. O. and Addadi, S, 1968, The vegetative propagation of tropical guava (Psidium guajava L.) in the Sudan. Sudan Agriculture J., 3: 12-20.

Tyagi, S. K. and Patel, R. M., 2004, Effect of growth regulators on rooting of air layering of guava (Psidium guajava L.) cv. Sardar. Orissa J. Hort., 32 (1): 5862.

Zamir, R., Khattak, G. S. S., Mohammad, T. and Ali, N., 2003, In vitro mutagenesis in guava (Psidium guajava L.). Pakistan J. Bot., 35 (5): 825-828

\section{How to cite this article:}

Manga, B., P. Jholgiker, G.S.K. Swamy, G. Prabhuling and Sandhyarani, N. 2017. Studies on Effect of Month and IBA Concentration of Air Layering in Guava (Psidium guajava L.) cv. Sardar. Int.J.Curr.Microbiol.App.Sci. 6(5): 2819-2825. doi: https://doi.org/10.20546/ijcmas.2017.605.318 